\title{
Naturopathic Reflex Therapies for the Treatment of Chronic Back and Neck Pain - Part 1: Neurobiological Foundations
}

\author{
Frauke Musial $^{\mathrm{a}}$ Dorothee Spohn ${ }^{\mathrm{b}}$ Roman Rolke \\ ${ }^{a}$ The National Research Center in Complementary and Alternative Medicine (NAFKAM), Department of Community Medicine, Faculty \\ of Health Science, University of Troms $\varnothing$, Norway \\ ${ }^{\mathrm{b}}$ AHG Klinik Tönisstein, Bad Neuenahr-Ahrweiler, \\ ${ }^{c}$ Department of Palliative Medicine, Rheinische Friedrich-Wilhelms-University, Bonn, Germany
}

\section{Keywords}

Naturopathic reflex therapies - Chronic pain .

Neurobiology · Cupping · Massage ·

Rhythmic embrocation - Manual therapies

\section{Summary}

Evidence from recent RCT's has shown that naturopathic reflex therapies such as massage, Gua Sha massage, cupping, wet packs, or rhythmic embrocation etc. are helpful in reducing symptoms of chronic pain. These bodily oriented therapies are likely able to influence chronic pain not only through brain mechanisms such as expectation or the feeling of well-being, but also through mechanisms at the level of the peripheral nociceptor and the spinal cord. However, the neurobiological basis of these effects has rarely been investigated even though the accumulating knowledge of the pathophysiology of chronic pain syndromes allows for developing specific hypotheses. This essay discusses specific reflex therapies (cupping, Gua Sha massage, classical massage, and rhythmic embrocation) and their possible mechanisms of action via ascending pathways to the brain.

\author{
Schlüsselwörter \\ Naturheilkundliche Reflextherapien . \\ Chronischer Schmerz · Neurobiologie · Schröpfen · \\ Massage $\cdot$ Rhythmisches Einreiben . \\ Manuelle Therapien
}

\section{Zusammenfassung}

In den letzten Jahren konnte durch randomisierte kontrollierte Studien die Wirksamkeit von naturheilkundlichen Reflextherapien wie klassische Massage, GuaSha-Massage, Schröpfen, Umschläge und rhythmisches Einreiben zur Linderung chronischer Schmerzsyndrome nachgewiesen werden. Vermutlich können diese auf den Körper ausgerichteten Therapien einen Teil ihrer Wirksamkeit nicht nur durch kognitiv beeinflussbare Mechanismen wie Erwartung oder positive Emotionen auf der Ebene des Vorderhirns entfalten, sondern auch auf der Ebene des Nozizeptors oder des Rückenmarks. Dennoch sind die neurobiologischen Grundlagen dieser Verfahren bisher noch unzureichend untersucht. Dabei erlaubt der Wissenszuwachs im Bereich der Schmerzforschung durchaus spezifische Hypothesen zur Wirkungsweise dieser Therapien. Dieses Essay erörtert die spezifischen Reflextherapien (Schröpfen, Gua-ShaMassage, klassische Massage und rhythmisches Einreiben) und ihre potenzielle Wirkungsweise entlang des schmerzverarbeitenden Systems vom Rezeptor bis zum Gehirn.

\section{KARGER \\ Fax +497614520714}

Information@Karger.com

www.karger.com (c) 2013 S. Karger GmbH, Freiburs

$1661-4119 / 13 / 0203-0219 \$ 38.00 / 0$

Accessible online at:

www.karger.com/fok
Frauke Musial, $\mathrm{PhD}$

National Research Center in Complementary and Alternative Medicine (NAFKAM) Department of Community Medicine, Faculty of Health Science, University of Troms 9037 Troms $\varnothing$, Norway

frauke.musial@uit.no 


\section{Clinical Background}

Chronic pain does not only impose a severe strain to those who suffer from it, it can furthermore not be 'healed' in a classical sense. Chronic pain conditions of the back, such as lumbago and/or neck pain, play a prominent role in clinical practice and are essentially characterized by muscle pain and thus relate to deep somatic origin. Like visceral pain [1], deep somatic pain is dull, difficult to localize [2], and difficult to treat. Chronic pain conditions affecting the neck and lower back are clinically highly relevant [3-8]: The lifetime prevalence for neck pain is approximately $48-66 \%$ and for lower back pain $51-84 \%$. Of these patients $9-18 \%$ suffer from severe chronic neck pain and $15-37 \%$ from severe chronic back pain [3-5, 7-10]. Therefore, both syndromes are already of high socioeconomic relevance and the incidence is still increasing.

Over the last years, the utilization of alternative methods of pain management is rising $[11,12]$ and there is accumulating evidence, that some of these interventions are helpful in alleviating chronic pain. A subgroup of these therapies, the so called reflex therapies (a group of therapies with a large overlap to manual therapies), is suspected to unfold most of its effects on the basis of reflex pathways via the spinal cord $[13,14]$. These reflex therapies are only partially included in the heterogeneous groups of interventions subsumed under the definition of 'manipulative and body based practices' of the NCCAM (http://nccam.nih.gov/health/backgrounds/ manipulative.htm). The aim of this paper is to provide a 'theory of problem' concerning the hypothesized mechanism of action of these groups of therapies, focusing on the modulation of ascending pain pathways. In a second methodological essay [67] the 'quantitative sensory testing' (QST) battery is suggested as a translational tool for the investigation of the biological mechanisms of this group of therapies.

\section{From the Spinal Cord to the Brain: Signal Processing in Nociception and Pain}

Nociceptive information from the periphery is transmitted by thinly myelinated $\mathrm{A} \delta$-fibers and slowly conducting, unmyelinated C-fibers, and enters the spinal cord through the dorsal horn. Here, these so-called primary afferent neurons excite second order neurons via neurotransmitters [15, 16]. Their cell bodies in the spinal ganglia synthesize transmitters and proteins that are involved in a circuit, leading to peripheral vasodilatation, plasmaextravasation, or trophic changes of the nociceptive nerve fiber endings [15]. In addition, visceral afferent neurons can influence tissue blood flow after inflammation $[17,18]$. The spinal cord as the first 'relay station' of the central nervous system (CNS) acts already as an active element in the pre-processing of the ascending pain information. A striking phenomenon associated with the specificities of information processing at the level of the spinal cord is the phenomenon of referred pain: Referred pain means that visceral pain is also felt in defined somatic areas. It is hypothetized that the convergence of somatic and visceral afferents on the same multireceptive interneurons in the dorsal horn results in referred pain [19-21].

In their further ascend to the brain, the axons of the nociceptive dorsal horn neurons cross the midline and travel upwards in the anterolateral column. All sensory information from the periphery is conveyed via the dorsal horn of the spinal cord in modality-specific sensory neurons. Fibers that extend to the brain from the dorsal horn and reach the medial and lateral portions of the thalamus are called the spinothalamic tract $[15,16]$. Once the ascending information reaches the brain level, modulatory influences by descending pathways from rostral ventromedial medulla (RVM) and periaqueductal gray matter (PAG), a structure which is heavily involved in descending pain inhibition (e.g., during stress), play a significant role in intrinsic pain control [16]. Both impulses after non-painful as well as painful stimulation reach the thalamus representing the next relay station of the nociceptive system. Information from the medial thalamus is projected to the anterior cingulate gyrus (ACC) and the insular cortex [22], whereas information from the lateral part of the thalamus projects to the somatosensory areas SI, SII, and insular cortex [23]. The ACC and insular cortex represent correlates of the affective-emotional dimension of pain, while SI and SII are part of the sensorydiscriminative pain network (fig. 1). However, the suggested organization of cortical pain processing networks may be different for visceral pain which is most likely a priori processed in the affective pain processing network $[14,17]$.

Moreover, there is also a second spino-cortical system called the posterior column-medial lemniscal system, which is unrelated to pain perception, but carries information on light touch, vibration, and proprioception [14]. This information travels ipsilaterally in the dorsal column to the brain and crosses the midline at the level of the brainstem (medulla). From there it extends via the thalamus to the precentral gyrus, the primary sensory cortex (fig. 1).

\section{Nociceptive Pain}

In chronic pain conditions, especially in deep somatic pain (e.g., back pain) sensitization of nociceptive neurons (i.e. threshold lowering or increased firing in reaction to adequate stimuli; or spontaneous activity of nociceptors) is observed. Sensitization can be due to chronic inflammation and subsequent changes of the nociceptor and its environment $[2,15$, 18]. Moreover, in chronic pain conditions, the distinction between mechanosensitive information (A $\beta$-fibers) and nociceptive (A $\delta$-and $\mathrm{C}$-fibers) information in the spinal cord seems to fail. This hypothesis refers to the phenomenon of 'allodynia' where pain in response to a non-nociceptive stimulus occurs $[18,25,26]$. The more specific term 'dynamic mechanical al- 
Fig. 1. The spino-thalamo-cortical and the dorsal column - medial lemniscal system. It is hypothesized that therapies inducing longer lasting therapeutic injuries of the skin are likely to stimulate the spino-thalamic tract, while therapies with apparently little or no nociceptive stimulation will unfold their effect through the lemniscal system.

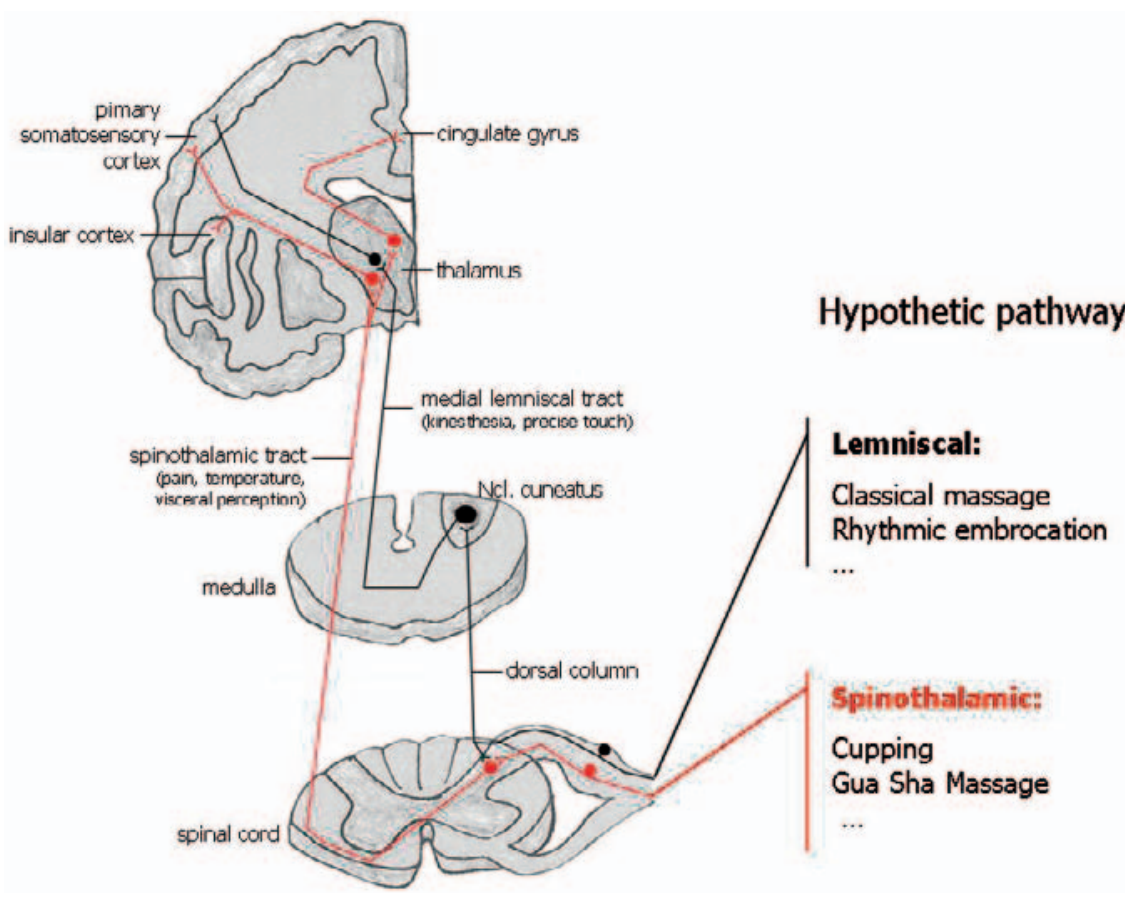

lodynia' describes painful sensations when mechanosensitive $A \beta$-fibers are stimulated (e.g., by dress fabric). There are several competing explanations for this phenomenon. Some authors favor a model in which mechanosensitive $A \beta$-fibers extend from deeper layers III-IV into superficial layers of the spinal cord where nociceptive fibers synapse with second order neurons [27-31] - an explanatory model which has however been questioned [32]. Another hypothesis suggests altered chloride homeostasis of spinal multireceptive neurons (on which mechanosensitive and nociceptive fibers converge) as the origin of sustained dorsal horn hyperexcitability, a phenomenon which seems to be influenced by microglia $[33,34]$. Nonetheless, all these models favor a prominent role of spinal cord reorganization in dynamic mechanical allodynia.

A second symptom of chronic pain attributed to reorganizational processes in the spinal cord is sustained increased pain sensitivity due to hyperactivity of dorsal horn neurons, the so-called hyperalgesia, [25]. It is hypothesized that chronic inflammatory processes result in hyperactivity of multireceptive wide dynamic range (WDR) dorsal horn neurons and subsequently lead to heightened synaptic transmission [35]. Baron [35] suggested the loss of inhibitory interneurons in the spinal cord as a possible mechanism of hyperalgesia, while Ziegler et al. [36] postulated that chemosensitive Cfibers facilitate spinal cord transmission of nociceptive $A \delta$ fibers. This so-called heterosynaptic facilitation could then result in secondary (centrally mediated) hyperalgesia, which is predominately restricted to increased responsiveness after sharp mechanical stimulation [36]. Primary hyperalgesia is a phenomenon elicited on the level of the primary (peripheral) nociceptive neurons [37]. It may result as a consequence of continuing tissue irritation such as in chronic low back pain or neck pain, where these peripheral impulses are generated from deeper tissues, e.g., muscles, tendons, or other bony structures.

Other brain regions not primarily involved in nociceptive processing, such as attention and expectation, are also known to play a role in pain perception [38]. Chronic pain may even lead to cortical changes $[39,40]$ and can thus alter attention and memory-related processes [39]. Moreover, Geber et al. [41] proposed even long-lasting somatosensory cortex reorganization following long-term nociceptor stimulation, similar to processes that seem to play a role in phantom limb pain $[42,43]$.

In conclusion, nociceptive chronic pain may arise following tissue trauma, even though this injury is no longer detectable as a pathological correlate. Mechanisms such as allodynia and primary or secondary hyperalgesia, as well as possible neuroplastic changes in the brain contribute substantially to the chronification of pain. Or, as Jänig [13] points out, there are 3 known mechanisms by which pain may chronify without direct damage to the nociceptive system (as in neuropathic or phantom pain): i) changes in the environment of the nociceptors (e.g., in chronic inflammation the nociceptors are intact but overactive); ii) neuroplastic changes at the level of the spinal cord (neuronal reorganization); iii) attention-dependent or emotional processes that have an effect on the functional realm of the motivational-affective pain network. It is furthermore unlikely that the 3 mechanisms can be separated from one another. Rather, chronic pain probably develops as a complex process with each of the 3 mechanisms contributing to various degrees [14]. 
Table 1. Hypothetic pathways for naturopathic reflex therapies

\begin{tabular}{llll}
\hline Nociceptor stimulation & Intervention & Peripheral sensory channel & Spinal/brainstem pathway \\
\hline Likely & cupping (wet and fire cupping) & C-fibers, A $\delta$-fibers & spinothalamic \\
& Gua Sha massage & C-fibers, A $\delta$-fibers & \\
Unlikely & classical massage & A $\beta$-fibers & lemniscal \\
& rhythmic embrocation & A $\beta$-fibers & \\
\hline
\end{tabular}

\section{Some Common Reflex Therapies and Their Hypothesized Ascending Pathways}

\section{Therapies, Likely to Induce Nociceptor Stimulation}

Cupping is an ancient technique for the treatment of several pain states [44]. There are different cupping techniques but the utilization of a glass cup in order to create suction over a painful area is common to all of them. Dry or fire cupping is used on the intact skin and induces the typical cupping marks (bluish bruises with the effusion of blood), while incisions to the skin with the aim of blood letting are applied during wet or bloody cupping [45]. Systematic clinical and observational studies have provided suggestive evidence for the effectiveness of cupping in the management of pain conditions [45-51].

Gua Sha massage is a traditional East Asian healing technique in which the painful body region is lubricated with oil and afterwards press-stroked by a smooth, rounded edge of a Chinese soupspoon without incising the skin. Stroking is performed until a petechial pattern is seen all over the treated area [52]. Although the Gua Sha causes massive petechiae and ecchymosis, patients often feel immediate pain relief during treatment. In a study in persons with localized myalgia [52] this reduction in pain was observed to continue for at least 2 days. Gua Sha is associated with a dramatic increase in blood circulation in the stimulated areas for up to $25 \mathrm{~min}[52,53]$.

Therapies like cupping or Gua Sha massage induce massive changes or even injuries to the skin. Tissue trauma leads to increased blood flow to the environment of the nociceptor, followed by an increased concentration of histamine, serotonin, potassium ions, prostaglandins, and bradykinin, as well as interleukins and tumor necrosis factor $\alpha(\mathrm{TNF}-\alpha)$. All these factors sensitize the peripheral nociceptor [15]. Thus these therapies can be expected to activate nociceptors and stimulate $\mathrm{A} \delta$ and C-fibers for prolonged time periods (likely as long as the skin injury lasts). It can be expected that they involve the spinothalamo-cortical pain pathways (fig. 1).

\section{Therapies, Likely to Induce Predominantly \\ Mechanosensitive Stimulation}

Classical massage: The forms of massage discussed here are techniques manipulating tissue with hands or mechanical devices [54]. There is good evidence from clinical studies [55] and systematic reviews $[54,56]$ that massage ameliorates pain in patients with nonspecific low back pain (subacute or chronic), that the effects might last for at least 1 year, and that massage is a safe therapy [57].
Rhythmic embrocation: Rhythmic embrocation is a very gentle form of massage out of the therapeutic spectrum of anthroposophical medicine, applying manual strokes of different intensities in a standardized manner. There is first evidence that rhythmic embrocation is an effective tool to alleviate chronic back pain [58].

These interventions are unlikely to stimulate C- or A $\delta$ fibers (at least not to a very large extend), thus they are also unlikely to involve the spino-thalamo-cortical system substantially. It is more likely, that this non-nociceptive input is mediated via large diameter $A \beta$-fibers. Thus, they can be expected to unfold their effect mostly through the dorsal column - medial lemniscal system, transmitting information about touch, vibration, and proprioception [24] (fig. 1). The fact that there is good clinical evidence for the beneficial effects of these therapies [54-57] is particularly interesting, since chronic pain patients often exhibit an increased sensitivity to low threshold A $\beta$-fiber input (allodynia) $[18,25,26,59]$. It can be speculated that nonnociceptive input, mediated via large diameter $\mathrm{A} \beta$-fibers, is also able to inhibit nociceptive C- or A $\delta$-fiber-mediated input, originating from painful body tissues. This inhibition seems to be located at the dorsal horn level of the spinal cord [60].

Furthermore, soft manipulation of skin is mostly perceived as being pleasurable and massage has been shown to even have an anxiolytic effect [61]. Thus, these techniques are highly likely to induce emotional and attentional processes on the cortical level, fostering relaxation and thus inducing beneficial effects on pain perception on a more systemic level. Feeling comfortable has been assumed to lead to enhanced distribution of endogenous opioids. This in turn might lead to an amelioration of endogenous pain control [62] (table 1).

\section{Conclusion}

Pain is a complex process and phenomenon, involving peripheral as well as central mechanisms. Over the last decades, the role of the spinal cord has received increasing attention and recognition in pain research and it is well-established, that the spinal cord is an active player in pain processing. Interestingly enough, it seems likely that some of the naturopathic reflex therapies exert a very direct effect on spinal nociceptive processing in that they themselves activate these pathways. But if that holds true, they can be expected to interfere with the pain phenotype of the treated chronic pain patient(s). Is it possible that this group of therapies utilizes or even alters the 
ascending nociceptive (spino-thalamic) or mechanosensitive (lemniscal) pathway to unfold their therapeutic effects? And if so, can a possible treatment effect via ascending pathways be measured?

The QST battery introduced by Rolke et al. [63-65] for the investigation and quantification of clinical pain provides the means for assessing treatment effects from the level of the peripheral nociceptor to the brain. QST is a set of standardized neurophysiological tests which provoke and analyze reactions of a subject's or patient's pain processing system and thus provides information about heightened or decreased sensitivity for a certain modality or sensory pathway. Part 2 [67] introduces QST as a translational tool for the investigation of reflex therapies.

Most investigations on the effect of alternative pain treatments, such as cupping [46, 45], Gua Sha massage [49], or classical massage [57], have shown substantial clinical effects but have limited their endpoints to subjective parameters such as the degree of pain or the feeling of well-being, which, even though they are doubtless highly relevant, reflect only attention-dependent and emotional processes at the cortical level. Furthermore, even though functional magnetic resonance studies have greatly enhanced our understanding of cortical processes, nonetheless, with rare exceptions [66] all functional imaging techniques are limited to the brain performance, which means, that they can only give a picture of the net effect of pain processing. Strictly speaking, these methods represent the last common network, but are limited in their ability to investigate the pathway and the origin of the signal. Nonetheless, the cortical mechanisms related to attentional and emotional processes, such as relaxation, the patient-practicioner relationship, or the feeling of elation, and the importance of these mechanisms for the therapeutic process and the well-being of the patient are greatly appreciated.

\section{Acknowledgements}

We are thankful to Åsa Sohlen for indispensable technical support. This manuscript was supported by a grant from the Faculty of Health Science, University of Troms $\varnothing$.

\section{Disclosure Statement}

The authors declare that they have no conflict of interest.

\section{References}

1 Musial F, Häuser W, Langhorst J, Dobos G, Enck P: Psychophysiology of visceral pain in IBS and health. J Psychosom Res 2008;64:589-597.

2 Schaible HG: Basic mechanisms of deep somatic pain. Chapter 41; in McMahon SB, Koltzenburg M (eds): Wall and Melzack's Textbook of Pain. Amsterdam, Elsevier, 2006, pp 621-633.

3 Andersson GBJ: Epidemiological features of chronic low-back pain. Lancet 1999;354:581-585.

4 Cassidy JD, Carroll LJ, Cote P: The Saskatchewan health and back pain survey. The prevalence of low back pain and related disability in Saskatchewan adults. Spine 1998;23:1860-1866.

$\checkmark 5$ Côte P, Cassidy JD, Carroll L: The Saskatchewan health and back pain survey. The prevalence of neck pain and related disability in Saskatchewan adults. Spine 1998;23:1689-1698.

6 Hillman M, Wright A, Rajaratnam G, Tennant A Chamberlain MA: Prevalence of low back pain in the community: implications for service provision in Bradford, UK. J Epidemiol Community Health 1996;50:347-352.

7 Mäkelä M, Heliovaara M, Sievers K, Impivaara O, Knekt P, Aromaa A: Prevalence, determinants, and consequences of chronic neck pain in Finland. Am J Epidemiol 1991;134:1356-1367.

8 Schochat T, Jäckel WH: Prevalence of low back pain in the population. Rehabilitation 1998;37:216223.

9 Guez M, Hildingsson C, Stegmayr B, Toolanen G: Chronic neck pain of traumatic and non-traumatic origin: a population-based study. Acta Orthop Scand 2003;745:576-579.

10 Johannes CB, Le TK, Zhou X, Johnston JA, Dworkin RH: The prevalence of chronic pain in United States adults: results of an Internet-based survey. J Pain 2010;11:1230-1239.
Bramwell B, Ferguson S, Scarlett N, Macintosh A: The use of ascorbigen in the treatment of fibromyalgia patients: a preliminary trial. Altern Med Rev 2000;5:455-462.

12 Herman PM, Szczurko O, Cooley K, Mills EJ: Cost-effectiveness of naturopathic care for chronic low back pain. Altern Ther Health Med 2008;14: 32-39.

13 Jänig W: Grundlagen von Reflextherapien; in Bühring M, Kremer FH (eds): Naturheilverfahren und unkonventionelle Medizinische Richtungen. Berlin, Springer, 2005, pp 1-104.

14 Musial F, Michalsen A, Dobos G: Functional chronic pain syndromes and naturophathic treatments: neurobiological foundation. Forsch Komplementmed 2008;15:97-103.

15 Todd AJ, Koerber HR: Neuroanatomical substrates of spinal nociception. Chapter 4; in McMahon SB, Koltzenburg M (eds): Wall and Melzack's Textbook of Pain, ed 5. Amsterdam, Elsevier, 2005, pp 73-90.

16 Fields HL, Basbaum AI, Heinricher MM: Central nervous system mechanisms of pain modulation. Chapter 7; in McMahon SB, Koltzenburg M (eds): Wall and Melzack's Textbook of Pain, ed 5. Amsterdam, Elsevier, 2009, pp 125-142.

17 Jänig W: The Integrative Action of the Autonomic Nervous System. Neurobiology of Homeostasis. Cambridge, Cambridge University Press, 2006.

18 Meyer RA, Ringkamp M, Campbell JN, Raja SN: Peripheral mechanisms of cutaneous nociception; in McMahon SB, Koltzenburg M (eds): Walls and Melzack's Textbook of Pain, ed 5. Amsterdam, Elsevier, 2006, pp 3-34.

19 Jänig W, Morrison JFB: Functional properties of spinal visceral afferents supplying abdominal and pelvic organs with special emphasis on visceral nociception. Prog Brain Res 1986;67:87-114.
20 Jänig W, Häbler HJ: Physiology and pathophysiology of visceral pain (in German). Schmerz 2002;16: 429-446.

21 Arendt-Nielsen L, Schipper KP, Dimcevski G, Sumikura H, Krarup AL, Giamberardino MA, Drewes AM: Viscero-somatic reflexes in referred pain areasevoked by capsaicin stimulation of the human gut. Eur J Pain 2008;12:544-551.

22 Graig AD: Pain mechanisms: labeled lines versus convergence in central processing. Annu Rev Neurosci 2003;26:1-30.

23 Apkarian AV, Bushnell MC, Treede RD, Zubieta JK: Human brain mechanisms of pain perception and regulation in health and disease. Eur J Pain 2005;9:463-484.

24 Gardner E, Martin J, Jessel TM: The bodily senses; in Kandel ER, Schwartz JH, Jessel M (eds): Principles of Neural Science, ed 4. New York, Mc GrawHill, 2000, pp 430-450.

25 Loeser, JD, Treede RD: The Kyoto protocol of IASP basic pain terminology. Pain 2008;137:473-477.

26 Devor M: Response of nerves to injury in relation to neuropathic pain; in McMahon S, Koltzenburg M (eds): Wall and Melzack's Textbook of Pain, ed 5. Amsterdam, Elsevier 2006, pp 905-927.

27 Koerber HR, Mirnics K, Brown PB, Mendell LM: Central sprouting and functional plasticity of regenerated primary afferents. J Neurosci 1994;14: 3655-3671.

28 Nakamura S, Myers RR: Myelinated afferents sprout into lamina II of L3-5 dorsal horn following chronic constriction nerve injury in rats. Brain Res 1999;818:285-290.

29 Okamoto M, Baba H, Goldstein PA, Higashi H, Shimoji K, Yoshimura M: Functional reorganization of sensory pathways in the rat spinal dorsal horn following peripheral nerve injury. J Physiol 2001;532:241-250. 
30 Torebjörk HE, Lundberg LE, LaMotte RH: Central changes in processing of mechanoreceptive input in capsaicin-induced secondary hyperalgesia in humans. J Physiol 1992;448:765-780.

-31 Woolf CJ, Shortland P, Coggeshall RE: Peripheral nerve injury triggers central sprouting of myelinated afferents. Nature 1992;355:75-78.

32 Bao L, Wang HF, Cai HJ, Tong YG, Jin SX, Lu YJ, Grant G, Hökfelt T, Zhang X: Peripheral axotomy induces only very limited sprouting of coarse myelinated afferents into inner lamina II of rat spinal cord. Eur J Neurosci 2002;16:175-185.

33 De Koninck Y: Altered chloride homeostasis in neurological disorders: a new target. Curr Opin Pharmacol 2007;7:93-99.

34 Coull JAM, Beggs S, Boudreau D, et al.: BDNF from microglia causes the shift in neuronal anion gradient underlying neuropathic pain. Nature 2005;438:1017-1021.

-35 Baron R: Mechanisms of disease: neuropathic pain - a clinical perspective. Nat Clin Pract Neurol 2006;2:95-106.

-36 Ziegler EA, Magerl W, Meyer RA, Treede, RD: Secondary hyperalgesia to punctate mechanical stimuli. Central sensitization to A-fibre nociceptor input. Brain 1999;122(Pt 12):2245-2257.

37 LaMotte RH, Lundberg LE, Torebjörk HE: Pain, hyperalgesia and activity in nociceptive $\mathrm{C}$ units in humans after intradermal injection of capsaicin. J Physiol 1992;448:749-764.

38 Wiech K, Ploner M, Tracey I: Neurocognitive aspects of pain perception. Trends Cogn Sci 2008;12: 306-313.

-39 Apkarian AV, Baliki MN, Geha PY: Towards a theory of chronic pain. Prog Neurobiol 2009;87:8197.

-40 Saadé NE, Jabbur SJ: Nociceptive behavior in animal models for peripheral neuropathy: spinal and supraspinal mechanisms. Prog Neurobiol 2008;86: 22-47.

41 Geber C, Magerl W, Fondel R, Fechir M, Rolke R, Vogt T, Treede RD, Birklein F: Numbness in clinical and experimental pain - a cross-sectional study exploring the mechanisms of reduced tactile function. Pain 2008;139:73-81.

42 Flor H, Elbert T, Knecht S, Wienbruch C, Pantev C, Birbaumer N, Larbig W, Taub E: Phantom-limb pain as a perceptual correlate of cortical reorganization following arm amputation. Nature 1995;375: 482-484.

43 Weiss T, Miltner WHR, Adler T, Brückner L, Taub E: Decrease in phantom limb pain associated with prosthesis-induced increased use of an amputation stump in humans. Neurosci Lett 1999;272:131-134.

44 Chirali IZ: Traditional Chinese Medicine Cupping Therapy. Philadephia, Elsevier, 2007.

45 Farhadi K, Schwebel DC, Saeb M, Choubsaz M, Mohammadi R, Ahmadi A: The effectiveness of wet-cupping for nonspecific low back pain in Iran a randomized controlled trial. Complement Ther Med 2009;17:9-15.
46 Michalsen A, Bock S, Lüdtke R, Rampp T, Baecker M, Bachmann J, Langhorst J, Musial F, Dobos GJ: Effects of traditional cupping therapy in patients with carpal tunnel syndrome: a randomized controlled trial. J Pain 2009;10:601-608.

47 Lüdtke R, Albrecht U, Stange R, Uehleke B: Brachialgia paraesthetica nocturna can be relieved by 'wet cupping' - results of a randomised pilot study. Complement Ther Med 2006;14:247-253.

48 Kim JI, Lee MS, Lee DH, Boddy K, Ernst E: Cupping for treating pain. A systematic review. Evid Based Complement Alternat Med 2011;2011:467014.

49 Braun M, Schwickert M, Nielsen A, Brunnhuber S, Dobos G, Musial F, Lüdtke R, Michalsen A: Effectiveness of traditional Chinese 'gua sha' therapy in patients with chronic neck pain: a randomized controlled trial. Pain Med 2011;12:362-369.

50 Lauche R, Cramer H, Choi KE, Rampp T, Saha FJ, Dobos GJ, Musial F: The influence of a series of five dry cupping treatments on pain and mechanical thresholds in patients with chronic non-specific neck pain - a randomised controlled pilot study. BMC Complement Altern Med 2011;11:63.

51 Lauche R, Cramer H, Hohmann C, Choi KE, Rampp T, Saha FJ, Musial F, Langhorst J, Dobos G: The effect of traditional cupping on pain and mechanical thresholds in patients with chronic nonspecific neck pain: a randomised controlled pilot study. Evid Based Complement Alternat Med 2012;2012:429718.

52 Nielsen A, Knoblauch NTM, Dobos GJ, Michalsen A, Kaptchuk TJ: The effect of gua sha treatment on the microcirculation of surface tissue: a pilot study in healthy subjects. Explore (NY) 2007;3: 456-466.

53 Kwong KK, Kloetzer L, Wong KK, Ren JQ, Kuo B, Jiang Y, Chen YI, Chan ST, Young GS, Wong ST: Bioluminescence imaging of heme oxygenase-1 upregulation in the gua sha procedure. J Vis Exp 2009;pii:1385.

54 Furlan AD, Brosseau L, Imamura M, Irvin E: Massage for low-back pain: a systematic review within the framework of the Cochrane Collaboration Back Review Group. Spine 2002;27:1896-1910.

55 Cherkin DC, Eisenberg D, Sherman KJ, Barlow W, Kaptchuk TJ, Street J, Deyo RA: Randomized trial comparing traditional Chinese medical acupuncture, therapeutic massage, and self-care education for chronic low back pain. Arch Intern Med 2001; 61:1081-1088.

56 Cherkin DC, Sherman KJ, Deyo RA, Shekelle PG: A review of the evidence for the effectiveness, safety, and cost of acupuncture, massage therapy, and spinal manipulation for back pain. Ann Intern Med 2003;138:898-906.
57 Sherman KJ, Cherkin DC, Hawkes RJ, Miglioretti DL, Deyo RA: Randomized trial of therapeutic massage for chronic neck pain. Clin J Pain 2009;3: 233-238.

58 Ostermann T, Blaser G, Bertram M, Michalsen A, Matthiessen PF, Kraft K: Effects of rhythmic embrocation therapy with solum oil in chronic pain patients: a prospective observational study. Clin J Pain 2008;3:237-243.

59 Woolf CJ, Doubell TP: The pathophysiology of chronic pain - increased sensitivity to low threshold A beta-fibre inputs. Curr Opin Neurobiol 1994; 4:525-534.

60 Moore KA, Baba H, Woolf CJ: Synaptic transmission and plasticity in the superficial dorsal horn. Prog Brain Res 2000;129:63-80.

61 Sherman KJ, Ludman EJ, Cook AJ, Hawkes RJ, Roy-Byrne PP, Bentley S, Brooks MZ, Cherkin DC: Effectiveness of therapeutic massage for generalized anxiety disorder: a randomized controlled trial. Depress Anxiety 2010:27:441-450.

62 Esch T, Stefano GB: The neurobiology of pleasure, reward processes, addiction and their health implications. Neuro Endocrinol Lett 2004:25:235-251.

63 Rolke R, Baron R, Maier C, Tolle TR, Treede RD, Beyer A, Binder A, Birbaumer N, Birklein F, Bötefür IC, Braune S, Flor H, Huge V, Klug R, Landwehrmeyer GB, Magerl W, Maihöfner C, Rolko C, Schaub C, Scherens A, Sprenger T, Valet M, Wasserka B: Quantitative sensory testing in the German Research Network on Neuropathic Pain (DFNS): standardized protocol and reference values. Pain 2006;123:231-243.

64 Rolke R, Baron R, Maier C, Tolle TR, Treede RD, Beyer A, Binder A, Birbaumer N, Birklein F, Bötefür IC, Braune S, Flor H, Huge V, Klug R, Landwehrmeyer GB, Magerl W, Maihöfner C, Rolko C, Schaub C, Scherens A, Sprenger T, Valet M, Wasserka B: Quantitative sensory testing in the German Research Network on Neuropathic Pain (DFNS): standardized protocol and reference values. Pain 2006;123:231-243. Erratum in Pain 2006; 125:197.

65 Rolke R, Magerl W, Campbell KA, Schalber C, Caspari S, Birklein F, Treede RS: Quantitative sensory testing: a comprehensive protocol for clinical trials. Eur J Pain 2006;10:77-88.

66 Eippert F, Finsterbusch J, Bingel U, Büchel C: Direct evidence for spinal cord involvement in placebo analgesia. Science 2009;326:404.

67 Spohn D, Musial F, Rolke R: Naturopathic reflex therapies for the treatment of chronic pain - part 2: quantitative sensory testing as a translational tool. Forsch Komplementmed 2013;20:225-230. 